\title{
An Exploration of Role of Human Resource Practices in Sales Department
}

\author{
${ }^{1}$ Param Agrawal, ${ }^{2}$ Apurva Narkhede, ${ }^{3}$ Amir H. Khan \\ ${ }^{1,2}$ Student, Department of Management Technology, \\ ${ }^{3}$ Assistant Professor, Department of Management Technology, \\ Shri Ramdeobaba College of Engineering \& Management, RamdeoTekdi, Gittikhadan, Katol Road, Nagpur \\ Email: agrawalpv@rknec.edu,narkhedeap@rknec.edu,khanah@rknec.edu
}

Received: $20^{\text {th }}$ September 2018, Accepted: $11^{\text {th }}$ October 2018, Published: $31^{\text {st }}$ October 2018

\begin{abstract}
The purpose of the study is impelled by the need to empirically test the role of human resource practices in the sales department of the organization with special emphasis on the practices such as to recruit, train, deploy, retain and reward the right sales talent. The relationship between the sales and human resource department can proved to be of a company's most valuable relationship leading to the improvement in the productivity, effectiveness and efficiency of the organization. Qualitative data is collected from the sales professionals of the selected companies. An exploratory study was also conducted to understand factors help in establishing the association between sales and human resource practices. It was also analyzed whether these features fit together with the satisfaction level of workers to be able to work productively and efficiently. The current study signifies the importance of human resource practices from the organizations' perspective. The findings of the study provide insights about the level of implementation of human resource practices in the sales department of selected organizations and to find out gaps for further improvement.
\end{abstract}

\section{Keywords \\ Human Resource Practices, Sales Department, Efficiency, Productivity}

\section{Introduction}

Human resources practices is important for shaping behaviours and attitudes of the employees in the organisations leading to better outcomes (Arthur, 1994; Huselid, 1995; Wood \& De Menezes, 1998).

Mainly employees' high commitment leads to high involvement and hard work to accomplish the goals of organisation and this is achieved by organisation's human resource policies and procedure (Ellen M. Whitener).

Sales department consist of market research, advertising, sales correspondence, sales, service, packaging, warehouse which need a strong sales team split into multiple role with unique functions. Human resource helps the sales to apply a higher level of discipline to talent management so that the sales organization is capable of performing at its best. They give them an understanding of the duties performed by people in different sales roles and realize that with the knowledge of recruitment, job description, screening candidates, personality testing, compensation packages etc.( Jennifer Mc farlane on July 7, 2014.)

It is said that the company's most valuable relationship is the true partnership between sales team and human resource. So as to source and recruit right kind of talent in the sales team it is important for $\mathrm{hr}$ to understand how various roles work together within the sales department.

\section{Literature Review}

As sales team needs to have specialised skills of selling and marketing techniques for the new-age customers in the market, HR has to develop the practices aligned with the sales department and its requirements. It was concluded that HR practices have the ability to impact the sales functions in the most positive manner. It includes recruitment of right talent, employee training and overall nurturing.HR practices ensures effective contribution in driving the sales effectively. The companies have develop the importance of good relations with the employees so it is important for them to engage HR practices effectively in the sales field leading to engagement of right talent in the department and its growth (Hanif Khaki, 2006). In the fast phase development sales training is necessary to improve job performance whereas previously it was improved with passage of experience.

Through training of sales personnel it decreases the turnover rate, recruitment and selection cost is reduced and overall efficiency \& productivity of the selling is increased. Training needs are identified and accordingly sales related techniques, marketing policies, background, market experience etc is inculcated is HR training.

Sales personnel motivation is important aspect for satisfactory job performance through skilled leaders in the sales department for the purpose. Compensation playing the important part in the HR, compensation structure need to be 
identified and evaluation is done according to the sales position for satisfactory rewards, bonus, fringe benefits and other extraordinary rewards for achievement of desired targets in the sales.

Real time insight into the performance of the sales team is the way one can solve the issues evolved during work and can improve the sales process which can be achieved by constant evaluation of sales department.

Sales productivity is also improved by the culture build in the sales team organisation where management creates an environment of safety and empathy. This leads to continuous improvement in the efficiency of the sales personnel without any fear as they have trust in the organisation with respect to the compensations and rewards offered to them.

\section{Methodology}

The data is collected with the help of qualitative technique and basically the research design use was descriptive and explorative method. For the data collection, we have selected 20 prominent companies and were contacted. The data is gathered through personal interaction and visit in every company. The questioner was not prepare for filling or collection of data (Google Questioner).And the data is analysed by using a non-parametric test such as frequency test, etc.

Data Analysis \& Interpretation

\begin{tabular}{|c|c|c|c|c|c|c|c|c|}
\hline \multirow{2}{*}{ Practices } & \multirow{2}{*}{ Count } & \multicolumn{7}{|c|}{ Sectors } \\
\hline & & Services & FMCG & Manufacture & Beverage & Automobile & Electronics & Retail/Apparel \\
\hline \multicolumn{9}{|l|}{$\begin{array}{l}\text { Recruitment } \\
\text { \& Selection. }\end{array}$} \\
\hline $\begin{array}{l}\text { Campus } \\
\text { Selection }\end{array}$ & 12 & $\mathrm{I}, \mathrm{L}, \mathrm{D}, \mathrm{C}, \mathrm{P}$ & $\mathrm{N}, \mathrm{PG}$ & PIX & K & $\mathrm{TM}, \mathrm{AL}$ & $\mathrm{TC}$ & \\
\hline Walk-in & 9 & $\mathrm{~L}, \mathrm{~V}, \mathrm{D}, \mathrm{B}$ & $\mathrm{N}$ & & $\mathrm{P} \& \mathrm{Co}$ & TM & $\mathrm{TC}$ & $\mathrm{PN}$ \\
\hline Lateral Hire & 8 & I & N,AM,PG,S,P & & $\mathrm{P} \& \mathrm{Co}$ & & $\mathrm{C}$ & \\
\hline $\begin{array}{ll}\text { Online } & \text { Job } \\
\text { Portals } & \end{array}$ & 9 & I.V,D,B & $\mathrm{P}$ & PIX & $\mathrm{K}$ & $\mathrm{TM}$ & $\mathrm{TC}$ & \\
\hline $\begin{array}{l}\text { Internal } \\
\text { Reference }\end{array}$ & 13 & $\mathrm{~V}, \mathrm{D}, \mathrm{C}$ & AM,PG,HUL,S & & $\mathrm{P} \& \mathrm{Co}, \mathrm{K}$ & $\mathrm{TM}$ & $\mathrm{TC}$ & MT,PN \\
\hline Promotion & 0 & & & & & & & \\
\hline $\begin{array}{l}\text { Advertisement } \\
\text { in Newspaper }\end{array}$ & 9 & $\mathrm{~L}, \mathrm{C}$ & $\mathrm{AM}, \mathrm{S}$ & & & $\mathrm{TM}, \mathrm{AL}$ & $\mathrm{TC}$ & MT \\
\hline $\begin{array}{l}\text { Through } \\
\text { agency }\end{array}$ & 7 & $\mathrm{D}, \mathrm{B}$ & HUL,N & & & $\mathrm{TM}, \mathrm{AL}$ & $\mathrm{TC}$ & \\
\hline \multicolumn{9}{|l|}{ Training } \\
\hline Induction & 12 & $\mathrm{I}, \mathrm{L}, \mathrm{V}, \mathrm{D}, \mathrm{B}$ & $\mathrm{PG}, \mathrm{S}, \mathrm{P}$ & PIX & $\mathrm{P} \& \mathrm{Co}, \mathrm{K}$ & & $\mathrm{TC}$ & \\
\hline $\begin{array}{l}\text { For Improving } \\
\text { Performance }\end{array}$ & 17 & $\mathrm{I}, \mathrm{V}, \mathrm{D}, \mathrm{C}, \mathrm{B}$ & N,PG,HUL,P & PIX & $\mathrm{P} \& \mathrm{Co}, \mathrm{K}$ & $\mathrm{TM}, \mathrm{AL}$ & $\mathrm{TC}$ & MT,PN \\
\hline $\begin{array}{l}\text { For Career } \\
\text { Development }\end{array}$ & 4 & $\mathrm{~V}$ & HUL & & $\mathrm{K}$ & $\mathrm{AL}$ & & \\
\hline For Promotion & 7 & $\mathrm{I}, \mathrm{L}$ & & & $\mathrm{P} \& \mathrm{Co}, \mathrm{K}$ & & TC & MT,PN \\
\hline \multicolumn{9}{|l|}{$\begin{array}{l}\text { Compensatio } \\
\text { n }\end{array}$} \\
\hline Fixed & 8 & L,B & AM,HUL & PIX & $\mathrm{K}$ & & $\mathrm{TC}$ & MT \\
\hline $\begin{array}{ll}\text { Fixed } & + \\
\text { Variable } & \end{array}$ & 10 & $\mathrm{I}, \mathrm{V}, \mathrm{D}, \mathrm{C}$ & N,PG,HUL,S,P & & & $\mathrm{TM}$ & & \\
\hline $\begin{array}{l}\text { Only } \\
\text { Commission }\end{array}$ & 1 & & $\mathrm{P}$ & & & & & \\
\hline $\begin{array}{ll}\text { Fixed } & + \\
\text { Variable } & + \\
\text { Bonuses } & \\
\end{array}$ & 9 & $\mathrm{~L}, \mathrm{C}$ & $\mathrm{AM}, \mathrm{S}$ & & $\mathrm{P} \& \mathrm{Co}, \mathrm{K}$ & & $\mathrm{TC}$ & MT,PN \\
\hline \multicolumn{9}{|l|}{ Evaluation } \\
\hline By Supervisor & 6 & $\mathrm{~L}, \mathrm{~V}$ & AM,PG & & & TM & & PN \\
\hline $360^{\circ}$ & 3 & $\mathrm{~L}$ & PG & & $\mathrm{P} \& \mathrm{Co}$ & & & \\
\hline $180^{\circ}$ & 3 & I.L & & PIX & & & & \\
\hline
\end{tabular}


If we consider HR practice of recruitment \& selection procedure with respect to sales department. These are the companies which follow to recruit talented candidate for their post and as per requirement. From the data collected of various sectors and different companies, it has been seen that internal reference is the most preferred way for hiring, recruit and after that campus selection is used. In these data collection the service sector prefer the campus selection way and FMCG prefer lateral hire way to recruit. It was finding that one of the company of service sector i.e. Dominos uses all way to recruit and select the employees and staff which is available. Training is generally given for improving performance by all the companies to his employees and induction i.e. Introduction \& brief overview of company and about their post was also provided by most of the companies to his employees before starting their job. Only 4 companies focus on his employee's career development and provide training to them. As it will help them to enhance their capabilities \& skills for long term. It was seen that majorly companies provide compensation by comprising two components i.e. Fixed + Variable to their employees.

Also three components i.e. Fixed + Variable + Bonuses are also one of the main criteria for compensation considered by the company accordingly to their need and as per it required to motivate the employee to increase their sale \& other parameter as per the change in the environment or in the scenario of the sector.

Other parameter is evaluation. Which is necessary to find out the deviation from the set target (Benchmark) and what was achieved by them? It also give us the way or provide to find out the problem which are there and contribute to not achieve the target and to make plan accordingly for its solution \& to top management for policy formation. It was found out that, supervisor evaluation method is preferred to judge and set criteria, as it is a very easy and convenient way. It was evaluate while they are working or performing their role.

\section{Conclusion}

For current study, we have use non-parametric test and collected the data to full fill our objective of study and in the view of analysis done. So, we conclude that the company adopt the common practices which are for recruitment $\&$ selection in campus selection and internal reference. For training is improving performance of their employee and training accordingly. For compensation, company adopts Fixed + Variable pay method. For evaluation, companies prefer to do it by supervisor method. These are some of the most prefer practices adopted by the companies and by relevant sector we have consider in our study i.e. 20 prominent companies.

\section{References}

1. Ellen M. Whitener. Department of Management. McIntire School of Commerce. Journal of Management 27 (2001) 515-535, VA 22903, USA http://jom.sagepub.com/content/27/5/515

2. Sheridanand . James H. Killian. 5 ways HR \& sales must partner to increase sales force effectiveness, Sep. 17,2017,http://chally.com/5-ways-hr-sales-must-partner-to-increase-sales-force-effectiveness/

3. Nicki jenns..5 Ways HR Can Increase Sales Force Effectiveness. https://www.hrzone.com/community/blogs/nickijenns/5-ways-hr-can-increase-sales-force-effectiveness

4. Jennifer Mmcfarlane. how your hr department can help drive sales success. July 7, 2014

5. Snehashish Bhattacharjee. How can HR practices impact sales enablement. July 30,2016 https://www.peoplematters.in/article/strategic-hr/how-can-hr-practices-impact-sales-enablement-13760

6. Richard R. Still. Edward W. Cundiff. Norman A. P. Govni. SALES MANAGEMENT, fifth edition. Pearson.

7. ALI SABETI .How to improve sales productivity.(VICE PRESIDENT OF MARKETING AND SALES, ZEROCATER). https://www.salesforce.com/quotable/articles/strategies-to-improve-sales-productivity/ 